\title{
УДК 378.14:004.9
}

Мокрієв Максим Володимирович

доцент, канд.екон. наук, доцент кафедри інформаційних і дистанційних технологій Національний університет біоресурсів і природокористування України, Київ, Україна m.mokriiev@nubip.edu.ua ORCID: 0000-0002-6717-3884

\section{ІНТЕГРАЦІЯ НАВЧАЛЬНО-НАУКОВИХ ПІДСИСТЕМ В ЄДИНЕ ІНФОРМАЦЙНО-ОСВІТНС СЕРЕДОВИЩЕ}

(на базі відкритого програмного забезпечення)

\begin{abstract}
Анотація. Створення інформаційно-освітнього середовища вищого навчального закладу це процес впровадження та налаштування значної кількості підсистем його функціонування, куди відносять навчальну, наукову, управлінську та інші. При чому всі ці частини значною мірою інтегровані між собою, повинні передавати в інші підсистеми деякі дані та отримувати від них інші. Незважаючи на велику кількість праць присвячених дослідженням створення інформаційно-освітніх середовищ вищих навчальних закладів, більшість 3 них стосуються суто педагогічних та організаційних аспектів і зовсім мало розглядають питання практичної реалізації з наведенням реальних прикладів. Мета статті $\epsilon$ демонстрація технічних можливостей організації інформаційно-освітнього середовища вищого навчального закладу шляхом інтеграції різних програмних компонентів. При цьому, робиться спеціальний наголос на використанні елементів відкритого програмного забезпечення та інтеграції 3 популярними хмарними сервісами. Використовуючи методи аналізу попередніх досліджень, порівняння описаних в них підходів та шляхом практичної перевірки було визначено можливий набір програмного забезпечення та технічної реалізації для створення інформаційно-освітнього середовища навчального закладу. В статті розглядається, що таке інформаційно-освітне середовище, з яких підсистем воно повинно складатися, і як технічно ці підсистеми та їхня взаємна інтеграція можуть бути реалізовані. Визначено, що використовуючи відкриті технології і відкрите програмне забезпечення українські навчальні заклади можуть створити власне інформаційно-освітнє середовище економлячи фінанси на ліцензійних відрахуваннях. Відкрите програмне забезпечення, з якого можна сформувати власне інформаційно-освітне середовище, в переважній більшості вже має варіанти інтеграції одне з одним на основі таких же відкритих стандартів. Важливо знати і розуміти можливості такої інтеграції. Ї̈̈ використання дозволить створити середовище під власні потреби та організаційні особливості кожного закладу. Можливість поступового підключення необхідних компонентів дозволить легше пройти процес впровадження інформаційно-освітнього середовища та залучення в нього всіх частин та відділів вищого навчального закладу. В статті на прикладах та 3 посиланнями продемонстровано можливості відкритого програмного забезпечення як складових частин інформаційно-освітнього середовища.
\end{abstract}

Ключові слова. інформаційно-освітне середовище; вищий навчальний заклад; інтеграція; відкрите програмне забезпечення; хмарні сервіси

Вступ. На етапі сьогодення, коли ми спостерігаємо швидкий перехід до нового інформаційного суспільства, навчальні заклади повинні також встигати за цим процесом. Інформатизація навчального процесу як і всієї іншої діяльності вищих навчальних закладів, зокрема передбачає побудову інформаційно-освітнього середовища.

Освітнє середовище вищого навчального закладу складається з різних підсистем, центральним з яких є єдине інформаційно-освітнє середовище. Основне призначення якого забезпечувати процес навчання студентів та надавати супутні до цього процесу інформаційні послуги.

Етап, коли освітні ресурси використовуються автономно, поступово відходить у минуле. Сьогодні вони стають носіями знань і інформації в рамках інформаційноосвітнього середовища навчального закладу, регіону, асоціації навчальних закладів або більш глобальних освітніх об'єднань. 
До початку другої ери електронного навчання, яке почалося з буму технологій Web 2.0, система електронних навчальних курсів була самодостатньою і не передбачала тісної інтеграції з іншими системами. Проте, бурхливий розвиток інтернет технологій та створення на їх основі веб-застосунків, які вже перестають поступатися традиційним прикладним програмам для персонального комп'ютера, надали величезну кількість додаткових сервісів. Все це значною мірою розширює можливості користувачів до надання та отримання знань.

При цьому, важливим $є$ не розпорошення зусиль та уваги учасників навчального процесу між різними сервісами, а максимальна інтеграція їх між собою.

Це бачення відповідає сучасним тенденціям швидкого розвитку інформаційнокомп'ютерних технологій. Найближчим часом учасникам навчального процесу потрібно буде враховувати та використовувати [1]:

- розширення можливостей у комунікаціях викладачів і студентів;

- забезпечення мобільності всіх наявних апаратних засобів;

- активізацію процесів оцифровування навчального контенту;

- нові сучасні інструменти керування великими обсягами інформації;

- навички обробки неструктурованої й непідготовленої інформації;

- планування розвитку з урахуванням хмарних технологій;

- активне підвищення кваліфікації викладачів і студентів у сфері інформаційних технологій;

- а також поява нових все складніших та водночас відкритих систем для підтримки різних компонентів навчального середовища вищого навчального закладу.

I якщо сьогодні вже не проблема встановити та налаштувати у себе систему підтримки електронних курсів, систему електронної бібліотеки або базу знань у вигляді дощок вікі, то при інтеграції цих компонентів між собою можемо стикатися з певними труднощами. Кожна з таких підсистем має власну базу даних для зберігання інформації, власний API та набір методів для роботи з інформацією, власні інтерфейси взаємодії 3 іншими системами.

Аналіз останніх досліджень. Питання побудови інформаційно-освітнього середовища, як в межах навчального закладу так і в більш глобальному розумінні давно досліджується як українськими так і світовими вченими. I розглядається в різних аспектах: педагогічному, організаційному, технічному та інше. Такі українські вчені як Н.Морзе [2], О.Спірін [3], В.Кухаренко [4], О.Глазунова та багато інших активно вивчають та просувають організаційно-педагогічні аспекти організації та функціонування інформаційно-освітнього середовища. Менша кількість робіт спостерігається в дослідженні організаційно-технічних аспектів побудови інформаційно-освітнього середовища. Тут можна згадати Титових [5] та О.М.Соколюка [6]. I ще менше можна знайти досліджень на інтеграцію компонентів інформаційноосвітнього середовища побудованого на відкритому програмному забезпеченні. Частина авторів, наприклад [7], розглядають функціональні можливості відкритих систем, які можна використати в інформаційно-освітньому середовищі, проте не аналізують можливості взаємної інтеграції та сумісності.

Проте, багато розробників програмного забезпечення вже здійснюють практичну можливість інтеграції тих чи інших компонентів у свої програмні продукти, розробляють нові стандарти взаємної інтеграції. Наша задача зібрати такі розрізнені компоненти використовуючи їх інтеграційні можливості в єдине інформаційно-освітнє середовище i визначити методику формування цілісної інформаційно-освітньої системи на базі відкритого програмного забезпечення. 
Мета статті - розглянути сучасні технічні можливості інтеграції окремих компонентів інформаційно-освітнього середовища вищого навчального закладу, які побудовано на основі відкритого програмного забезпечення, в єдине середовище.

Виклад основного матеріалу. В подальшому розгляді нас буде цікавити інтеграція різних програмних систем, яка повинна забезпечити вільний та максимально простий перехід користувачів з однієї підсистеми у іншу, а також максимально проста передача навчальних даних між цими підсистемами.

Можемо прочитати у великому тлумачному словнику української мови, що інтеграція це “об”єднання в ціле будь-яких окремих частин” або “процес упорядкування, узгодження та об'єднання структур і функцій у цілому організмі” [8]. Наше інформаційно-освітне середовище повинно виступати як цілісний організм. Отже, i підхід інтеграції до його компонентів повинен бути відповідним.

У контексті веденого нами дослідження під інтеграцією розумітимемо етапи створення інформаційно-освітнього середовища, які полягають в поєднанні різних програмних засобів навчального та інформаційного призначення 3 метою отримання нових і підвищення існуючих функціональних можливостей.

Побудова інформаційно-освітнього середовища передбачає використання та взаємну інтеграцію різних інформаційних систем та їх компонентів. Таким чином, щоб складалася система взаємодоповнюючих елементів, які допомагають виконувати основні функції: навчання та контролю.

Основними складовими такого середовища є [9]:

- навчальна система представлена електронними навчальними курсами, базами знань та електронною бібліотекою;

- наукова система представлена електронними науковими журналами та інтернетконференціями, а також портфоліо студентів та викладачів;

- система управління навчальним процесом представлена системою управління деканатом та університетом;

- система обліку користувачів представлена єдиною базою користувачів інформаційно-освітнього середовища;

- та інші, як робота в хмарах, соціальних мережах тощо.

Зібрати всі ці компоненти в одному програмному продукті є дуже проблематично та відносно дорого фінансово. Тож доводиться інтегрувати різні програмні платформи для забезпечення потрібного функціоналу. Щоб здешевити процес створення та експлуатації, основний вибір робиться на відкриті хмарні технології та відкриті програмні продукти.

Для прикладу покажемо забезпечення основних складових. Інформаційно-освітнє середовище вищого навчального закладу може мати різноманітні підсистеми, перелік яких ми описали вище, проте до важливої та першочергової компоненти віднесемо навчальну систему на чолі 3 навчально-інформаційним порталом 3 електронними курсами, який забезпечує основну функцію вищого навчального закладу - навчання. I цю систему своїм функціоналом повністю може задовольнити LMS Moodle. Другим компонентом є електронна бібліотека, яка може працювати на платформі Dspace або ePrints. На цих же програмних продуктах може працювати сховище магістерських дипломних проектів.

Для наукової частини системи підходить платформа Open Conference, на якій можна реалізовувати інтернет-конференції університету.

Управління навчальним процесом реалізується через додаткові модулі Moodle, зокрема, важливе місце в ній займає модуль Subcourse.

Система обліку користувачів ведеться через базу openLDAP, в яку облікові дані студентів переконвертовуються з державної бази ЄДЕБО. 
В результаті всі компоненти починають працювати як єдине середовище.

Одна 3 основних складностей побудови такого інформаційно-освітнього середовища є поєднання між собою дуже різнопланових компонентів. Іншими словами, в результаті ми отримуємо складне гетерогенне середовище.

Навчальні ресурси в гетерогенному середовищі можна умовно поділити на такі три категорії: неоднорідність операційного середовища, неоднорідність сховищ навчальних даних, неоднорідність логічних зв'язків [10].

Неоднорідність операційного середовища представляється як різне апаратне та програмне середовище для функціонування системи, а також фізичне місце розташування та доступ до адміністрування різних частин. Тобто, частини інформаційно-освітнього середовища можуть розташовуватися локально в межах серверних потужностей університету, а можуть бути винесені на потужності провайдера послуг або як хмарні сервіси. Крім того, різні частини можуть працювати на різних операційних системах, що теж може провокувати різні неузгодженості при передачі інформації. I, врешті, останнє це абсолютно різні програмні системи під різні функції та задачі інформаційно-освітнього середовища, які в переважній більшості пишуться різними людьми.

До неоднорідності сховищ даних відноситься відмінність між системами зберігання навчальних ресурсів в різних частинах. Так певна частина зберігається в СУБД MySQL, інше в MS SQL Server, ще інше в хмарних сховищах Google або Microsoft.

Неоднорідність логічних зв'язків постає через різноманітність назв пов'язаних елементів даних, їх значення, граматики тощо. Теж значення може представляти іншу семантику в різних операційних середовищах та системах баз даних.

Яким же чином можна подолати описані неузгодженості між різними частинами створюваної системи? Вихід це інтеграція за допомогою стандартизованих технологій передачі інформації:

- передача даних за допомогою XML та JSON;

- аутентифікація за допомогою LDAP, OpenID та Oauth2 тощо.

Варіантом також може бути написання власних інтеграційних компонентів, які будуть компонувати та передавати дані з однієї підсистеми в іншу. Проте, цей підхід $є$ більш затратним ніж пошук вже готових інтеграційних можливостей у різних підсистемах. Але навіть такий спосіб потрібно враховувати там, де немає готових рішень.

Найпершою та найпростішою частиною інтеграції різних підсистем між собою є налаштування єдиної системи авторизації всіх користувачів.

Часи, коли кожна система працювала ізольовано і відповідно потребувала власної реєстрації своїх користувачів, давно минули. Цей застарілий підхід мав як мінімум дві величезні незручності:

1) потреба введення однієї тієї ж самої інформації в різні підсистеми, це потенційна можливість помилок та неузгодження цієї інформації в різних частинах; до цього потрібно додати великі витрати часу пов'язані з введенням а потім з адмініструванням;

2) користувачам доводиться подавати на реєстрацію ті ж самі свої дані в різні підсистеми, утримувати різні облікові записи, пам'ятати різні паролі для кожної підсистеми.

Чудовим прикладом організації єдиної системи авторизації є Google.

Але Google надає не лише один обліковий запис, але й єдину точку входу до всіх своїх ресурсів. Таким чином, користувачі не лише використовують один пароль для всього, але й вводять його один раз, а потім вільно переходять між різними сервісами.

В ідеалі навчально-інформаційне середовище повинно працювати так само. Але різниця між Google та середовищем, яке ми намагаємося вибудувати, в тому, що Google 
має фінансові та людські ресурси для написання власного інструментарію, який враховує всі нюанси окремих сервісів, а ми намагаємося будувати інтегровану систему 3 розрізнених підсистем.

Однією з головних об'єднувальних частин такої системи є єдина система аутентифікації, що передбачає як перший крок єдину базу даних користувачів, а в подальшому єдиний вхід.

Потрібно також зауважити, що відносно низька культура використання подібних інтернет систем несе з собою певні загрози. Так, єдина точка входу дає доступ до всіх підсистем не лише користувачу, але також і зловмиснику, що тягне за собою небезпеку доступу до конфіденційної інформації, навмисному пошкодженню системи тощо.

Натомість, на нашу думку, єдиний обліковий запис але без єдиної точки входу зменшить небезпеку небажаного проникнення в систему через людський фактор, оскільки потребуватиме від користувача введення пароля для під'єднання до кожної 3 підсистем. В цьому випадку, навіть, якщо зловмисник потрапить в одну з частин, він не 3 може зіпсувати всю систему.

Проте, 3 розвитком систем авторизації та вдосконаленням алгоритмів розпізнавання користувачів все одно відбудеться перехід до єдиної точки входу.

Останній часом такі компанії як Google та Microsoft надають спеціальні пропозиції для навчальних закладів по розміщенню своїх навчальних ресурсів у власних хмарах 3 доступом до багатьох їх сервісів. При цьому, заклад отримує також підтримку корпоративного домену з відповідною поштовою адресою. Тож, можна проводити автентифікацію через поштові сервіси Google та Microsoft. Або ж використати їх спеціальні сервіси для автентифікації OpenID та Oauth2. Потрібно відзначити, що все більше програмних продуктів включають у свою поставку можливість аутентифікації через зовнішні ресурси як Google та Microsoft.

Аналізуючи досвід розв'язання поставлених завдань зазначимо, що у Інституті інформаційних технологій і засобів навчання НАПН України проводилися дослідження стосовно інтеграції LMS MOODLE 3 хмарними сервісами Microsoft Office 365 [11]. Також, Тернопільський національний педагогічний університет імені Володимира Гнатюка проводив дослідження з інтеграції Moodle та Google Suite (до 2016 року Google Apps), Microsoft Office 365.

Варіант при якому університет веде базу користувачів в Google або в Office 365 передбачає отримання підписки в цих сервісах

Протокол OpenID дозволяє сайту упевнитися, що його користувач володіє персональним URL (своїм сайтом, блогом, профілем). Цього факту достатньо для того, щоб використовувати унікальний URL для розпізнавання того ж самого користувача наступного разу. Отож, OpenID - це протокол, який забезпечує автентифікацію на основі підтвердження достовірності клієнта третьою стороною - провайдером OpenID. У нашому випадку провайдером OpenID буде сервіс log-in.microsoftonline.com, а сайтом клієнтом - LMS Moodle.

OAuth $є$ відкритим протоколом авторизації, який дозволяє надати третій стороні обмежений доступ до захищених ресурсів користувача без необхідності передавати їй логін та пароль. Протокол OAuth забезпечує користувачів можливістю надавати сайтамклієнтам маркери доступу, до даних які розміщені на сайтах-сервісах.

Потрібно зауважити на важливий нюанс такої автентифікації через Google OAuth 2.0 він не підтримує перевірку в домені вашого університету. Таким чином, на сайт електронних курсів зможе зайти будь-хто, хто має обліковий запис в Google. Цю незручність можна обійти, якщо ввести користувачів вручну та заблокувати автоматичне створення нових з Google. 
При реєстрації через Office 365 такої проблеми не існує. Там можна вказати, що реєструватися мають право тільки записи вашого університетського домену.

На жаль, багато інших відкритих ресурсів, які можна пропонувати включити до інформаційно-освітнього середовища наразі не підтримують подібної автентифікації. I хоча звичайно, враховуючи відкритий код цих систем, можна власними силами розширити функціонал, ми пропонуємо інший підхід 3 використанням готових технологій.

Єдиною базою користувачів може слугувати база LDAP (англ. Lightweight Directory Access Protocol полегшений протокол доступу до директорій/каталогів) мережевий протокол прикладного рівня для надсилання запитів та модифікації даних служби каталогів через ТCP/IP [12].

3 технологією LDAP можна працювати через різні програми, найбільш популярними з яких є openLDAP та MS ActiveDirectory. Проте, потрібно зауважити, що ActiveDirectory добре працює тільки 3 продуктами Microsoft, a openLDAP, в силу своєї відкритості підтримується більшою кількістю програм. Але принципи роботи вони мають спільні.

Велика перевага LDAP в тому, що майже всі програмні продукти, які потребують авторизації, вміють його використовувати.

Як база даних LDAP представляє собою ієрархію каталогів (рис. 1).

1. Рівень університету $(\mathrm{dc}=\mathrm{nubip}, \mathrm{dc}=\mathrm{edu}, \mathrm{dc}=\mathrm{ua})$

1.1. Облікові записи (ou=people)

1.1.1. Викладачі (ou=staff)

1.1.1.1. Кафедри (оu=назва_кафедри)

1.1.2. Студенти (ou=students)

1.1.2.1. Факультет (оu=назва_факультету)

1.1.2.1.1. Напрям/Спеціальність (оu=назва_спеціальності)

1.1.2.1.1.1. Рік вступу (ou=piк)

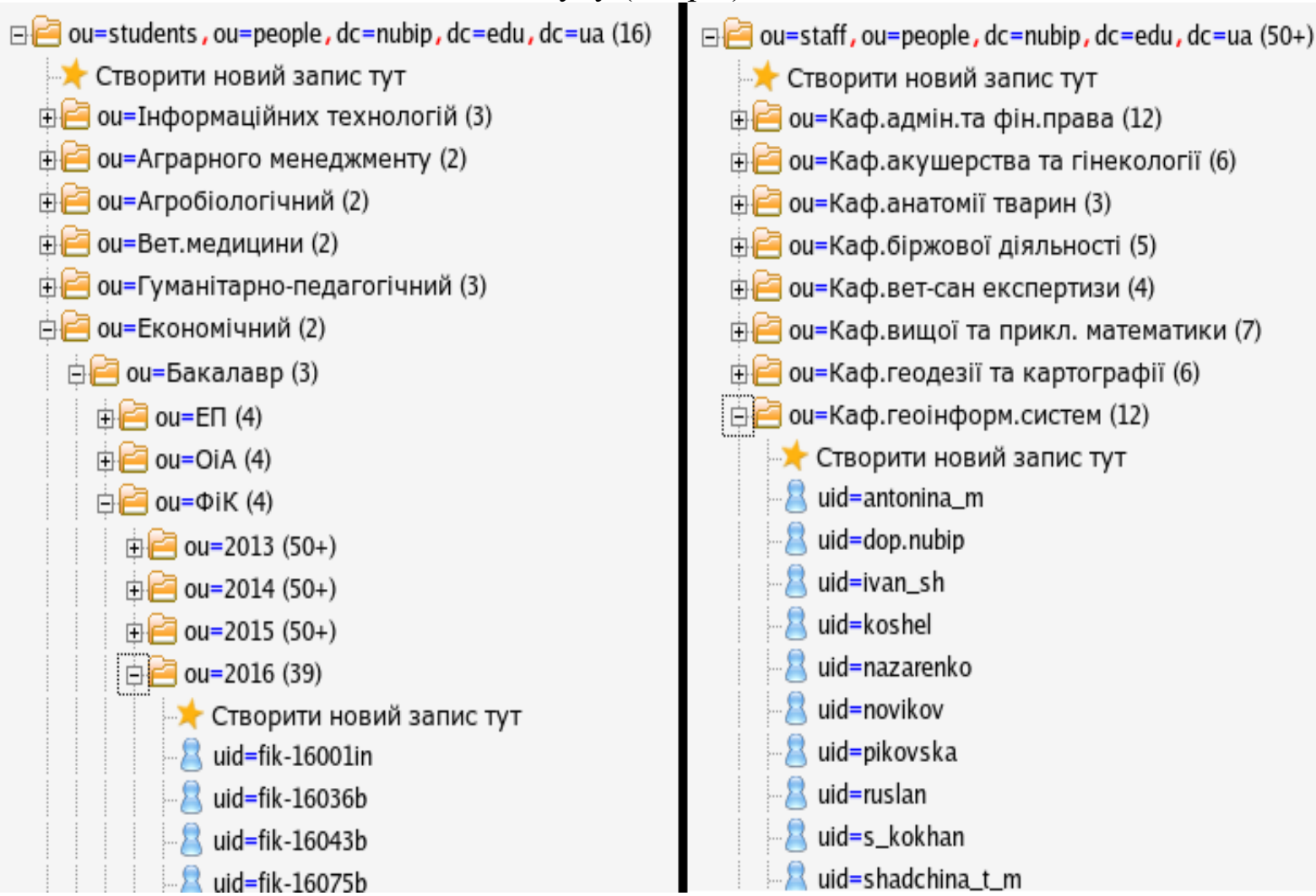

Рис. 1. Приклад ієрархії бази даних LDAP 
Кожен обліковий запис має повний набір полів 3 даними про користувача, які можуть бути потрібними в різних підсистемах інформаційно-освітнього середовища. Приклад картки облікового запису користувача можна переглянути на рисунку 2. Від бази LDAP може братися різна кількість інформації від мінімального логін-пароль, до повного набору даних.

Керувати базою користувачів, можна з різнопланового програмного забезпечення призначеного для роботи 3 LDAP. Проте найзручнішою програмою візуального керування є LDAP Account Manager [13]. Дана програма створюється на базі відкритих технологій, а розповсюджується в двох варіантах: відкритий безплатно та професійний платно. Професійна версія має в собі деякі специфічні модулі, які дозволяють мати додаткові можливості при роботі з базою LDAP. Наприклад, надати користувачам візуальний доступ до даних свого облікового запису напряму, а не через посередництво прикладних програм. При цьому. користувачі отримують можливість змінити дані свого облікового запису, додати відсутні дані, скинути пароль тощо.

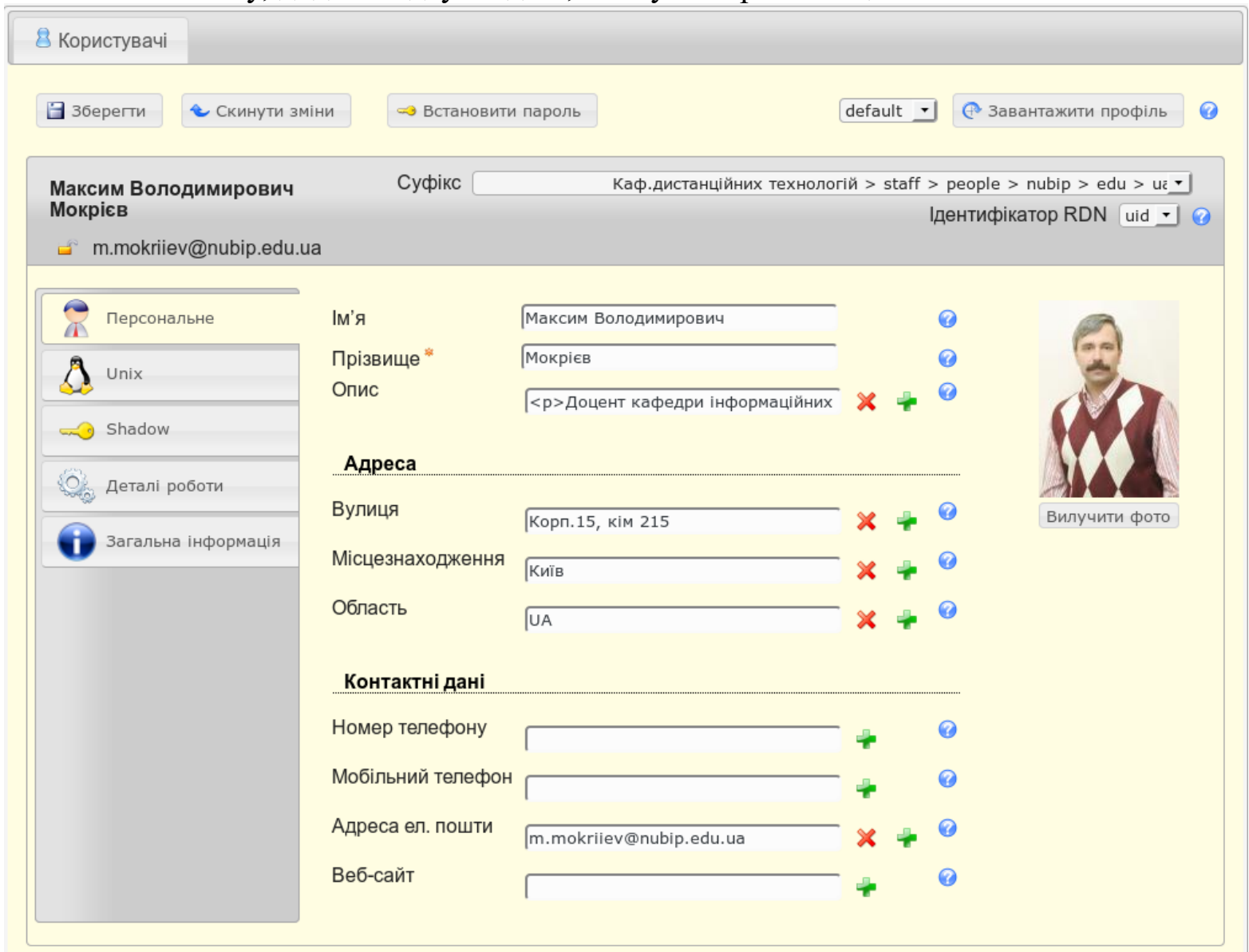

Рис. 2. Облікова картка викладача університету

В інших підсистемах потрібно лише правильно підключити модулі аутентифікації з прив'язкою їх до бази даних LDAP.

Наступний етап в процесі інтеграції компонентів інформаційно-освітнього середовища це взаємна інтеграція навчальних компонентів.

В комп'ютерних науках завжди існувала проблема повторного використання коду та інформації, щоб створене одного разу програмне забезпечення можна було легко переносити на інші платформи і використовувати в інших місцях, що дає великий ефект, економлячи час і кошти. 
3 точки зору навчальної інформації можемо застосувати той же підхід. На сьогодні на просторах інтернету є величезна кількість навчальних ресурсів, як відкритих так i закритих. Але і ті і інші можна використати як складові елементи навчальних курсів в нашому інформаційно-освітньому середовищі.

В цьому ракурсі можна розглядати як окремі сервіси, придатні для навчального процесу, так і цілі електронні курси, наприклад на МООС платформах, де студенти можуть отримувати інформацію, здійснювати навчально-практичну діяльність та отримувати за це оцінки.

При чому, виникає потреба не просто направити студентів на інші ресурси, а певним чином інтегрувати їх у власний електронний курс. Раніше для цього використовувався переносний формат електронних курсів SCORM [14]. Але він має суттєвий недолік: весь курс забирається на нашу платформу та втрачає зв'язок зі своїм оригіналом.

Наступний етапом вирішення цієї проблеми стала розробка стандарту Learning Tools Interoperability (LTI) засіб навчальної взаємодії [15]. Основна ідея тут створити розподілене навчальне середовище, яке передбачає спільне використання різних віртуальних середовищ, що взаємодіють з користувачем та між собою.

На сьогодні розроблено три версії цього стандарту (рис.3):

LTI 1.0 студенти переходять зі свого курсу на інший ресурс і можуть користуватися ним без додаткової реєстрації.

LTI 1.1 додатково дозволяє отримати назад у свій курс оцінки отримані у віддаленому ресурсі. При цьому, від ресурсу до ресурсу передаються потрібні для цього дані користувача.

LTI 2.0 надає ще більшу інтеграцію між ресурсами за рахунок передачі додаткових звітних даних.

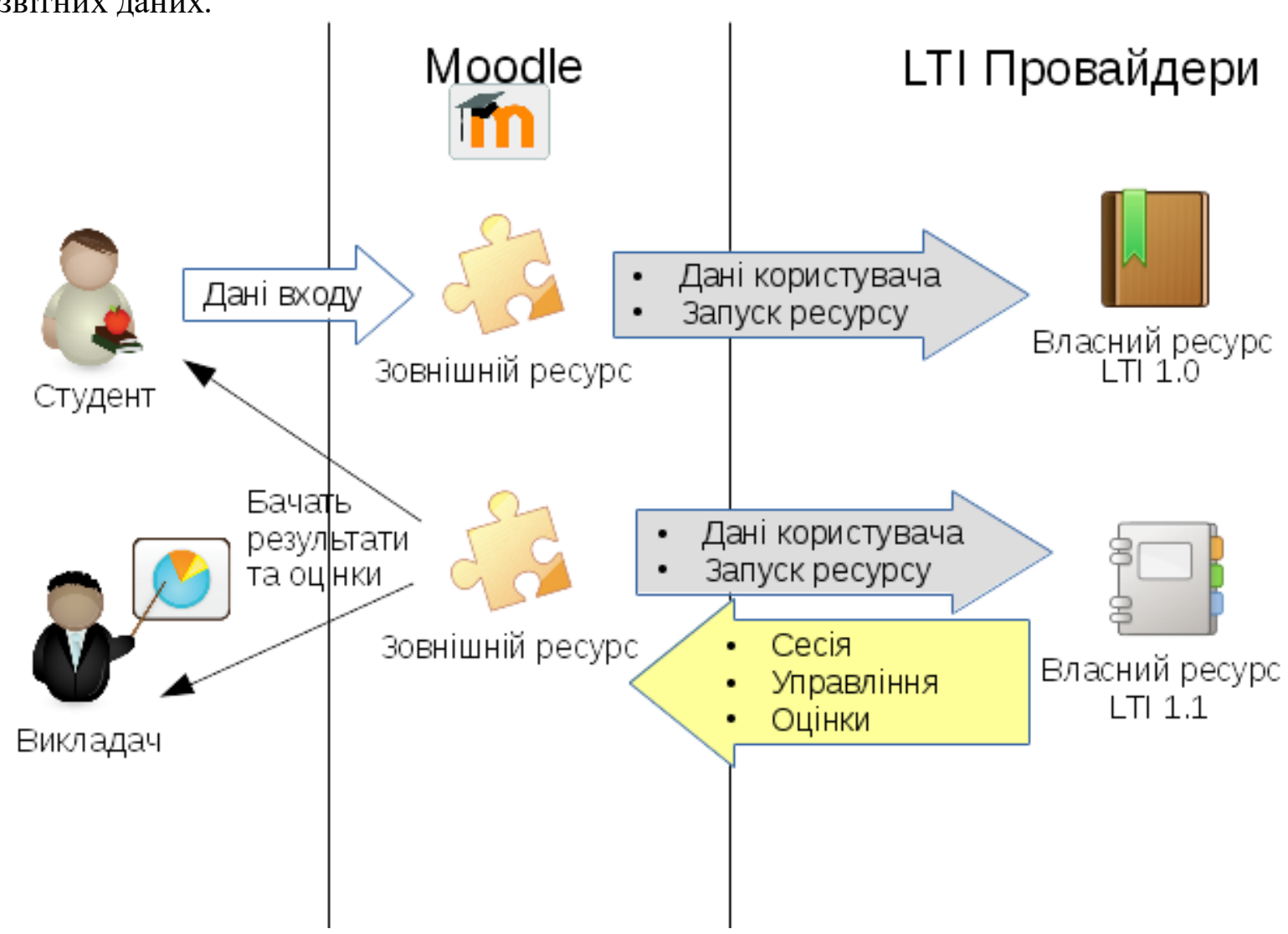

Рис. 3. Інтеграція навчальних ресурсів через стандарт LTI 
Варто зазначити, що до появи стандарту LTI задача інтеграції платформ дистанційного навчання 3 іншими програмними засобами вирішувалася шляхом створення спеціальних модулів. Однак недоліком такого підходу є те, що подібні модулі доводилося розробляти для кожної платформи і кожного зовнішнього програмного засобу, з яким вона інтегрується, а потім їх доводилось оновлювати при переході на кожну наступну версію як самої платформи, так і зовнішнього засобу.

Завдяки стандартизації, вже немає потреби ні розробляти, ні оновлювати такі модулі, якщо платформа і зовнішні програмні засоби підтримують стандарт LTI.

Для створення засобу зовнішньої діяльності потрібен постачальник засобів (провайдер), який підтримує стандарт LTI. Викладач може створити засіб зовнішньої діяльності або використати інструмент, налаштований адміністратором сайту.

Зовнішній засіб відрізняється від URL-ресурсів у декількох напрямках:

- зовнішні засоби контекстні, тобто вони мають доступ до відомостей про користувача, який запустив цей засіб, наприклад, такої, як установа, курс та ім'я;

- зовнішні засоби підтримують читання, оновлення та видалення оцінок, пов'язаних 3 цією діяльністю;

- конфігурації зовнішніх засобів створюють довірчі відносини між сайтом власника і провайдером, надаючи безпечний зв'язок між ними.

На сайті IMS Global Learning Consortium [16] на сьогодні налічується 501 програмний продукт, який пройшов офіційну сертифікацію на відповідність стандарту LTI 1.0, a їх неофіційний перелік та короткий огляд їх функціональних можливостей можна знайти також на сайті [17].

Висновки. Цілісне інформаційно-освітнє середовище можна побудувати на основі компонентів з відкритого програмного забезпечення, якого стає все більше і більше. Ці компоненти можна інтегрувати між собою на різних рівнях складності, починаючи від єдиної бази користувачів до передачі навчального та управлінського контентів.

Як показує дослідження, стандарт LTI відкриває можливості для інтеграції окремих віртуальних навчальних середовищ у єдине розподілене навчальне середовище, користувачі якого одержують можливість спільного використання розміщених на них ресурсів.

Така інтеграція може відбуватися на різних рівнях. Можна, наприклад, об'єднати в єдине навчальне середовище різні платформи, що належать одному навчальному закладу. Відкриваються можливості для кооперації між навчальними закладами, які можуть використовувати електронні навчальні ресурси один одного.

Перспективи подальших досліджень. Продовжуючи роботу над створенням інформаційно-освітнього середовища навчального закладу необхідно враховувати тенденції все більшого переходу користувачів у хмарні сервіси як відкриті так i корпоративні. Тому варто порівняти ризики та вигоди від повного переходу у “хмари" на базі платного і безоплатного використання та потребою базові підсистеми залишити повністю під контролем закладу.

\section{СПИСОК ВИКОРИСТАНИХ ДЖЕРЕЛ}

1. Топузов М.О. Проектування інформаційно-освітнього середовища навчальних закладів у сучасному суспільстві. Український педагогічний журнал. №1, 2017. C.26-36

2. Морзе Наталия Викторовна, Глазунова Елена Григорьевна. Способы интеграции цифрового контента в электронном учебном курсе. OTO. 2014. №1. URL: https://cyberleninka.ru/article/n/sposoby-integratsii-tsifrovogo-kontenta-v-elektronnomuchebnom-kurse (дата обращения: 11.04.2020). 
3. Биков, В.Ю., Спірін, О.М., Пінчук, О.П. Проблеми та завдання сучасного етапу інформатизації освіти. Наукове забезпечення розвитку освіти в Україні: актуальні проблеми теорії і практики (до 25-річчя НАПН України). 2017. С.191-198.

4. Кухаренко, В.М. Розвиток дистанційного навчання на сучасному етапі. Науковий вісник НАСОА. 2012. №2. С.117-121

5. Тітов, С. В., Тітова, О. В. Інформаційно-освітнє середовище навчального закладу: розвиток засобів і способів комунікаційної й інформаційної взаємодії. Вісник Харківської державної академії культури. 2014. №43. С.144-150.

6. Соколюк, О.М. Інформаційно-освітнє середовище навчання в умовах трансформації освіти. Наукові записки. Серія: Проблеми методики фізико-математичної i технологічної освіти. 2017. №3(12). С.48-55.

7. Ворожбит, А. В. Веб-орієнтоване інформаційно-освітнє середовище закладу освіти. Інформаційні технології в освіті. 2018. №3. С.20-29.

8. Великий тлумачний словник сучасної української мови : 250000 уклад. та голов. ред. В. Т. Бусел. Київ; Ірпінь: 2005. VIII, 1728 с.

9. Мокрієв М.В. Інтеграція Moodle в інформаційно-освітнє середовище університету. Четверта міжнародна науково-практична конференція "Moodle Moot Ukraine 2016. Теорія і практика використання системи управління навчанням". (Київ, КНУБА, 1920 травня 2016 р.): тези доповідей. Київ, 2016. С.12

10. Xia Yaowen, Li Zhiping, Lv Saidong, Tang Guohua. The Research and Application of heterogeneous database based on XML in Distance Education. Proceedings of the 2nd International Conference on Computer Science and Electronics Engineering (ICCSEE 2013). Published by Atlantis Press, Paris, France. 2220-2223pp.

11. Носенко Ю. Г. Інтеграція LMS Moodle з хмарним сервісом Microsoft Office 365: нові можливості для підтримки відкритої освіти. URL: http://2015.moodlemoot.in.ua/ course/view.php?id=104 (дата звернення: 17.01.2020)

12. LDAP. Стаття з Wikipedia. URL: https://uk.wikipedia.org/wiki/LDAP (дата звернення: 17.01.2020)

13. LDAP Account Manager. Сайт програми. URL: https://www.ldap-account-manager.org (дата звернення: 17.01.2020)

14. Стандарт SCORM и его применение. URL: http://cccp.ifmo.ru/scorm/index.html (дата звернення: 20.01.2020)

15. Learning Tools Interoperability. URL: http://www.imsglobal.org/activity/ learning-toolsinteroperability (дата звернення: 15.01.2020)

16. All Learning Tools Interoperability ${ }^{\mathrm{TM}}$ v1.0 Compliant Products. URL: http://www.imsglobal.org/cc/allblti.cfm?pageNum_rsBLTICompliance=1 (дата звернення: 17.01.2020)

17. Edu Apps. An open LTI app collection. URL: https://www.edu-apps.org (дата звернення: 17.01.2020)

\title{
INTEGRATION OF EDUCATIONAL SUBSYSTEMS IN AN ALL-IN-ONE INFORMATION AND EDUCATION ENVIRONMENT (with open source software)
}

\author{
Maksym Mokriiev \\ $\mathrm{PhD}$ (economic sciences), Associate Professor of the Department of Informational and Distant Technologies \\ National University of Life and Environmental Sciences of Ukraine, Kyiv, Ukraine \\ m.mokriiev@nubip.edu.ua \\ ORCID: 0000-0002-6717-3884
}

Abstract. Creating an information and educational environment of a higher education institution is the process of introducing and setting up a large number of subsystems - educational, scientific, 
managerial and others. All these parts are largely integrated with each other. They must transfer some data to other subsystems and receive from them. In spite of the large number of works devoted to the research of creation of information and educational environments of higher educational establishments, the majority of them concern only pedagogical and organizational aspects and very few consider the issues of practical implementation with real examples. The purpose of the article is to demonstrate the technical capabilities to organizing information and educational environment through the integration of various software components. In doing so, there is a special emphasis on the use of open source elements and integration with popular cloud services. It is a difficult and expensive task to collect all the subsystems required in the educational environment of a higher education institution. The cost of complex solutions from well-known brands is measured in thousands of dollars, and their implementation requires the same integrated approach. For Ukrainian educational institutions, the solution may be to build their own information and educational environment using open source components. In most cases, such programs already have options for integrating with one another based on the same open standards. It is important to know and understand the possibilities of such integration. Its use will allow to create environment for own needs and organizational features of each institution. The possibility of gradually connecting the necessary components will make it easier to go through the process of introduction of information and educational environment and involvement of all departments of higher education in it. The examples and links in the article demonstrate the potential of open source software as an integral part of the educational environment.

Keywords: information and educational environment; institution of higher education; integration; open source software; cloud services

\section{REFERENCES (TRANSLATED AND TRANSLITERATED)}

1. Topuzov, N. (2017). Designing of educational environment of educational institutions in modern society. Ukrajinsjkyj pedaghoghichnyj zhurnal, 1, 26-36. (in Ukrainian)

2. Morze, N. \& Hlazunova, O. (2014). Ways to integrate digital content in an e-learning course. OTO, №1.

https://cyberleninka.ru/article/n/sposoby-integratsii-tsifrovogo-kontenta-v-elektronnomuchebnom-kurse (in Russian)

3. Bykov, V., Spirin, O., \& Pinchuk, O. (2017). Problems and tasks of the modern stage of informatization of education. Scientific support for the development of education in Ukraine: current problems of theory and practice (to the 25th anniversary of the National Academy of Pedagogical Sciences of Ukraine), 191-198. (in Ukrainian)

4. Kukharenko, V. (2012). Development of distance learning at the present stage. Naukovy visnyk NASOA, 2, 117-121. (in Ukrainian)

5. Titov, S. \& Titova, O. (2014). Information and educational environment of an educational institution: development of means and methods of communication and information interaction. Visnyk Kharkivskoi derzhavnoi akademii kultury, 43, 144-150. (in Ukrainian)

6. Sokoliuk, O. (2017). Information-educational environment of education in conditions of education transformation. Naukovi zapysky. Seriya: Problemy metodyky fizykomatematychnoi i tekhnolohichnoi osvity, 3(12), 48-55. (in Ukrainian)

7. Vorozhbyt, A. (2018). Web-based educational and educational environment. Informacijni tekholohii v osviti, 3, 20-29. (in Ukrainian)

8. A great explanatory dictionary of modern Ukrainian: 250000 (2005). Kyiv, Irpin: Perun. (in Ukrainian)

9. Mokriiev, M. (2016). Integration of Moodle into the university's information and educational environment. Fourth International Scientific and Practical Conference "Moodle Moot Ukraine 2016. Teorija i praktyka vykorystannja systemy upravlinnja navchannjam". (Kyiv, KNUBA, 19-20 May 2016): abstracts. Kyiv, 12. (in Ukrainian)

10. The Research and Application of heterogeneous database based on XML in Distance Education (2013). Xia Yaowen, Li Zhiping, Lv Saidong, Tang Guohua. Proceedings of the 
2nd International Conference on Computer Science and Electronics Engineering (ICCSEE 2013). Published by Atlantis Press, Paris, France. 2220-2223pp.

11. Nosenko, Y (2015). Integration of LMS Moodle with Microsoft Office 365 Cloud Service: New Opportunities to Support Open Education. http://2015.moodlemoot.in.ua/course/view.php?id=104 (in Ukrainian)

12. LDAP. From Wikipedia. https://uk.wikipedia.org/wiki/LDAP

13. LDAP Account Manager. https://www.ldap-account-manager.org

14. SCORM standard and its application. http://cccp.ifmo.ru/scorm/index.html (in Russian)

15. Learning Tools Interoperability. http://www.imsglobal.org/activity/learning-tools-interoperability

16. All Learning Tools Interoperability ${ }^{\mathrm{TM}}$ v1.0 Compliant Products. http://www.imsglobal.org/cc/allblti.cfm?pageNum_rsBLTICompliance=1

17. Edu Apps. https://www.edu-apps.org 